\title{
GEOPOLÍTICA E ORGANIZAÇÕES
}

Vivemos um período de transição da hegemonia mundial, no qual países e blocos econômicos lutam para superar suas crises e aumentar seu peso nas decisões globais e sua participação na distribuição dos recursos planetários escassos. Geopolítica e Organizações é uma área ainda nascente da pesquisa em Administração, que procura entender o papel das organizações públicas, privadas e do terceiro setor, nacionais e internacionais, no jogo pelo poder global entre os diversos países.
Nesse jogo, as organizações são tanto causa quanto efeito do sucesso de um país. Buscando sair dos paradigmas ideológicos vigentes e da limitação da relação entre os fatores geopolíticos e as organizações ao conceito de risco político, a área busca construir análises e cenários realistas para que as organizações possam posicionar-se durante o atual período de incertezas. Antonio Gelis Filho, professor da FGV-EAESP, oferece aqui suas indicações sobre o tema.

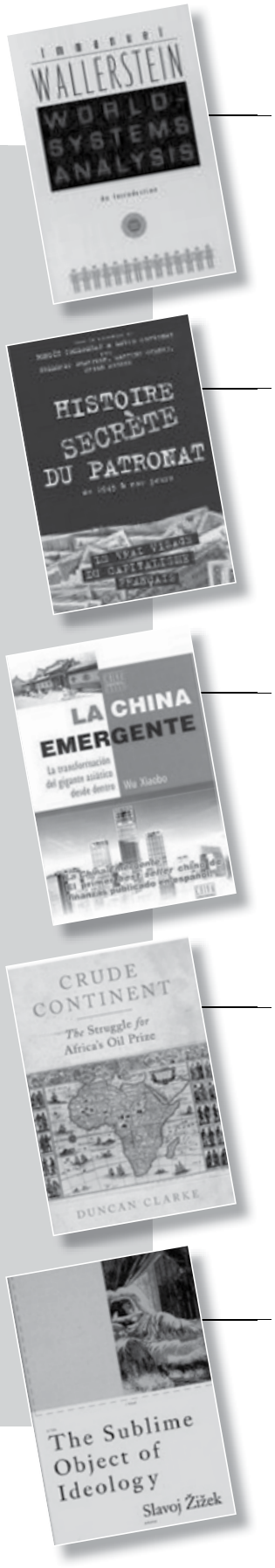

WORLD-SYSTEMS ANALYSIS: An introduction. Immanuel Wallerstein. Durham: Duke University Press, 2004. 109 p. 0 sociólogo norte-americano é um dos mais respeitados cientistas sociais vivos e um ativo pensador da esquerda mundial. Sua teoria do sistema-mundo oferece uma alternativa convincente à compreensão neoliberal vigente desde o final da Guerra Fria e que agora se encontra em crise. Sua análise da situação mundial parece explicar muitos dos fenômenos geopolíticos recentes.

HISTOIRE SECRÈTE DU PATRONAT: De 1945 à nos jours. Bennoît Collombat e David Servenay (Dirs.) Paris: La Découverte, 2009. 719 p. Patronat é uma expressão utilizada em referência às pessoas e grupos que controlam o grande capital na França. Nesta obra, os autores oferecem uma visão panorâmica da estreita, e frequentemente secreta, relação entre os governos franceses e as grandes empresas e grupos empresariais do país. Poucos livros cumprem melhor o papel de destruir as ilusões em relação à existência uma suposta mão invisível do mercado na construção da fortuna nacional.

LA CHINA EMERGENTE: La transformación del gigante asiático desde dentro. Wu Xiaobo. Beijing: China Intercontinental Press, 2009. 327 p. Publicado na China, este livro é um envolvente diário das transformações econômicas chinesas desde 1978, que consegue oferecer uma visão geral do processo sem se esquecer das estórias e dramas dos pequenos atores da economia. 0 autor faz isso, porém, sem deixar de destacar o papel de Deng Xiaoping e de sua política de desenvolvimento econômico na construção do milagre econômico chinês, processo esse que mudaria a distribuição do poder global.

CRUDE CONTINENT: The struggle for Africa's oil prize. Duncan Clarke. London: Profile Books, 2008. 674 p. Talvez nenhuma outra indústria sinta tão de perto os efeitos das disputas geopolíticas quanto a indústria de petróleo e gás. 0 autor deste livro, tendo passado parte de sua vida nessa atividade, oferece uma visão abrangente, e por vezes deprimente, do pesado jogo de poder econômico e político em torno do petróleo africano, envolvendo governos e empresas. Um jogo que, infelizmente, pouco beneficiou a população mais pobre do continente.

THE SUBLIME OBJECT OF IDEOLOGY. Slavoj Žižek. New York: Verso, 1989. 240 p. 0 filósofo esloveno é uma das mais polêmicas e brilhantes personalidades do pensamento crítico contemporâneo. Situando seu trabalho na intersecção entre Lacan, Marx e Hegel, Žižek, nesta obra, leva a geopolítica à sua fronteira última: a construção pessoal e inconsciente da ideologia. Ele mostra também, com base em exemplos históricos, como pode ser rápida a modificação da maneira de pensar das pessoas em resposta às crises. Infelizmente, um tema atual. 